\title{
Contribution of Naturalist Intelligence and Learning Participation toward Students' Knowledge Competence in Science
}

\author{
N M. Karisma Yulianti ${ }^{1}$, I G A. Oka Negara ${ }^{2}$, I W. Sujana ${ }^{3}$ \\ ${ }^{123}$ Prodi Pendididikan Guru Sekolah Dasar, Universitas Pendidikan Ganesha, Singaraja, Bali, Indonesia
}

\author{
ARTICLEINFO \\ Article history: \\ Received 2 Juni 2020 \\ Received in revised form \\ 12 Juli 2020 \\ Accepted 10 Agustus 2020 \\ Available online 28 Agustus \\ 2020 \\ kata kunci: \\ Kemampuan Naturalis, \\ Partisipasi Belajar, IPA \\ keywords: \\ Naturalist Intelligence, \\ Learning Participation, IPA
}

\begin{abstract}
A B S T R A K
Kompetensi pengetahuan IPA siswa terus berkembang karena dipengaruhi oleh faktor kecerdasan dan partisipasi. Kurangnya pemahaman tentang pentingnya partisipasi siswa untuk mendapatkan hasil belajar yang lebih optimal bukan lagi sebagai salah faktor yang diutamakan, sehingga siswa cenderung merasa malas, serta sulit untuk mengemukakan pendapat yang menyebabkan kompetensi pengetahuan IPA kurang meningkat. Penelitian ini bertujuan untuk menganalisis pengaruh yang signifikan kemampuan naturalis terhadap kompetensi pengetahuan IPA, pengaruh yang signifikan partisipasi belajar terhadap kompetensi pengetahuan IPA, dan pengaruh yang signifikan secara bersama-sama kemampuan naturalis dan partisipasi belajar terhadap kompetensi pengetahuan IPA siswa kelas IV. Jenis penelitan ini yaitu expost facto. Populasi dalam penelitian ini adalah seluruh siswa kelas IV yang berjumlah 490 siswa. Sampel ditentukan dengan teknik proporsional random sampling dan didapat jumlah sampel sebanyak 214 orang.
\end{abstract}

Pengumpulan data kemampuan naturalis dan partisipasi belajar didapat dengan penyebaran kuesioner dan kompetensi pengetahuan IPA didapat dengan pencatatan dokumen. Teknik analisis data yang digunakan yaitu analisis regresi linear berganda. Hasil penelitian menunjukkan bahwa terdapat pengaruh yang signifikan kemampuan naturalis terhadap kompetensi pengetahuan IPA dengan kontribusi sebesar 12,68\%, terdapat pengaruh yang signifikan partisipasi belajar terhadap kompetensi pengetahuan IPA dengan kontribusi sebesar $35,44 \%$, dan terdapat pengaruh yang signifikan kemampuan naturalis dan partisipasi belajar terhadap kompetensi pengetahuan IPA dengan kontribusi sebesar 48,12\%. Berdasarkan hasil penelitian, dapat disimpulkan kemampuan naturalis dan partisipasi belajar berkontribusi terhadap kompetensi pengetahuan IPA siswa kelas IV SD.

\begin{abstract}
A B S T R A C T
Science competence of students continues to develop because it is influenced by factors of intelligence and participation. Lack of understanding of the importance of student participation in obtaining more optimal learning outcomes is no longer one of the priority factors, so students tend to feel lazy, and find it difficult to express opinions which cause the competence of science knowledge does not increase. This study aimed to analyze the significant effect of naturalist ability on the competence of science knowledge, the significant effect of learning participation on the competence of science knowledge, and the significant effect together of naturalist ability and learning participation on the competence of science knowledge of fourth grade students. This type of research is ex-post facto. The population in this study were all fourth-grade students, amounting to 490 students. The sample was determined by proportional random sampling technique and obtained a total sample of 214 people. Naturalist ability data collection and learning participation were obtained by distributing questionnaires and competence in science knowledge was obtained by recording documents. The data analysis technique used was multiple linear regression analysis. The results showed that there was a significant effect of naturalist ability on the competence of science knowledge with a contribution of $12.68 \%$, there was a significant influence of learning participation on the competence of science knowledge with a contribution of 35.44\%, and there was a significant influence on naturalist ability and learning participation. to the competence of science knowledge with a contribution of $48.12 \%$. Based on the results of the study, it can be concluded that naturalist abilities and learning participation contribute to the competence of science knowledge of fourth grade elementary school students.
\end{abstract}




\section{Introduction}

Basic education is mandatory for all individuals. Basic education is an effort that is expected to be able to develop children's potential, namely the development of religious and moral values, social emotional development, language development, cognitive development, and physical (motor) development (Susilowati, 2014; Nurjanah, 2018) education of religious and moral values is closely related to the character of a child. But apart from all that, basic education is also expected to be able to launch the intelligence that every child naturally carries within him. It is because intelligence for a child has great benefits besides for himself and also for his interactions in life. Through a high level of intelligence, children will be more appreciated if they are able to take part in creating phenomenal new things. There are still many people who still interpret intelligence narrowly (Suhirman, 2017; Nurjanah, 2018) but through intelligence the child will grow into a human being with character. Intelligence is still considered a person's intellectual level in terms of academics only. Often parents and teachers give the predicate "smart" and smart only to those who have excellent academic achievement. Intelligence is only rewarded with scores which are the sum of all the answers that someone deems able to answer correctly.

Every child in this world has various intelligence in different levels and indicators (Rahman, 2018: Nurjanah, 2018) as for the intelligence in question is the intelligence intelligence, spiritual intelligence, and emotional intelligence. This shows that all children are intrinsically intelligent. The intelligence possessed by each child is very diverse and very important to be developed, including one of which is the naturalist ability (Syarifah, 2019; Juniarti, 2015) Natualist intelligence is the expertise in recognizing and classifying various species of flora and fauna. Naturalist abilities are very important to be developed because with this naturalist ability, individuals will understand the sustainability of their environment and can understand the benefits of the environment or the surrounding nature so that they will have an interest in preserving nature. Classifying children with naturalist abilities like to learn about nature, love animals, categorize species in the environment, are able to cultivate and utilize nature and protect it (Yaumi, 2013; Holili, 2018) naturalist abilities, namely the ability to recognize flora and fauna, to make coherent choices in the natural world and to use this ability productively, for example hunting, farming or doing biological research. One of the learning content related to the natural environment, including animals (fauna) and plants (flora), is science learning (Santiani, 2017; Widi et al, 2014) Science is said to be the main science, studying natural phenomena factually (factual), which in other words is called reality or events and their causal relationships. In the past, now, and in the future, IPA will play an important role in the natural world of human life that depends on nature, substances contained in nature, and all kinds that occur in nature. Through science learning, students have a high initiative to be involved in maintaining, preserving the natural environment, and respecting nature with everything in it as God's gift (Yaumi, 2013; Juniarti, 2015) Naturalist intelligence is very important, because with naturalist intelligence, children will fully realize the nature of caring for their surroundings.

For teachers in particular, they must be able to integrate naturalist abilities and link them into every science lesson in schools. Teachers and parents must be able to direct children to develop naturalist abilities consistently so that children will have high naturalist abilities (Maryanti, 2019; Husin 2017) parents and teachers must have sufficient knowledge about how to develop naturalist abilities and provide real examples to children about living things, the environment and nature and how to protect them. The higher the naturalist ability of the child, the greater the curiosity and involvement of the child in learning activities / activities in the classroom that can increase competence in science knowledge. This research has been linked by several relevant studies, namely research with the results of research showing that the development of naturalist abilities in living material material in the science learning content of fifth grade elementary school students is high (Istiana, 2017; Wijayanti, 2019) also showed that students need the ability of naturalists to achieve the predetermined competency standards of science graduates.

The learning process is a process where all the potential possessed by students is developed by the teacher. The learning process in educational units is organized in an interactive, inspiring, fun, challenging, motivating students to participate actively, and providing sufficient space for initiative, creativity, and independence according to the talents, interests, and physical and psychological development of students (Pramana, 2019; Sunhaji, 2014) The learning process is an attempt to make students learn, so that this situation is an event of learning, which is an attempt to change student behavior. The role of teachers, especially for elementary school students, cannot be replaced by other tools so that learning takes place effectively. Effective teaching is teaching that provides opportunities for self-study or doing activities on their own (Nurhayati, 2017; Lestari, 2018) students 
are not only tasked with receiving all kinds of information, but students must try to get and obtain information on their own. This means that effective learning requires student involvement in it. Students are placed as learners, who must be actively involved in the learning process. Students who try to experience and act during learning can form more meaningful patterns of knowledge for students. Student involvement in the process of learning activities to train student creativity is called learning participation (Wijayanti, 2013; Nurhayati, 2016) a learning process that is full of innovation and creation will be able to increase student learning participation.

By actively involving students, the learning process has been designed to develop cognitive, affective, and psychomotor aspects of students (Santiani, 2017; Santoso, 2018) emphasizing the main duties and responsibilities of a teacher or teacher is managing teaching more effectively, dynamically, efficiently, and positively which is characterized by awareness and active involvement between the two teaching subjects, the teacher as the initial initiator and the guide, while the students as the experience and be actively involved to obtain self-change in teaching. In other words, student participation is one of the principles that teachers need to pay attention to in the learning process. In addition, without student participation, the learning process may not take place well because the learning process involves interaction between students and educators. Therefore, efforts to increase learning participation can be applied in all subjects taught to students, including the content of learning science. One of the achievements of learning success in the classroom is marked by the participation of students who are actively involved in the process of learning activities which can improve competency in science knowledge (Shodiq, 2020; Nurhayati, 2016) The participation in question is the participation or involvement of students in activities carried out in the learning process.

But in reality, naturalist abilities and student learning participation are still not optimally implemented. This can be seen from the point of view of teachers and parents who feel that student's abilities are only limited to the lesson scores obtained at school, thus causing obstruction of other abilities possessed by students. Students feel free to explore their talents and interests because they are afraid of the consequences that will be received. Most teachers are still fixated on thinking that the learning given will be successful if students always get perfect test / exam scores. In fact, that is only one of the factors of student success during the learning process. Teachers tend to put aside other factors that can improve student competence. To optimize student abilities requires active participation during the learning process. However, we can see that there are not a few students who feel that learning is very boring because learning is still considered less attractive so that student competencies tend not to be achieved and meet the criteria. Teachers do not create diverse learning variations, lack of use of instructional media, and manage learning locations in schools. Because to foster naturalist abilities and increase participation, learning that is located outside the classroom can be used.

From the explanation of these problems, this study was conducted to determine the significant effect of naturalist ability on the fourth-grade students' competency in science knowledge of SDN Gugus III North Kuta for the academic year 2019/2020, the significant effect of learning participation on the competence of science knowledge of class IV SDN Gugus III Kuta. Utara Academic Year $2019 / 2020$, and the significant influence of naturalist abilities and learning participation on the competency of science knowledge of grade IV SDN Gugus III Kuta Utara students for the 2019/2020 academic year.

\section{Research Method}

This study was conducted at SDN Gugus III Kuta Utara using an ex-post facto design with a correlation research study. Ex-post facto research did not control for the independent variables directly. This study was an ex-post facto research because in this study there is no treatment for the research variables. This study only took data based on the existing measurements of the correspondents. This study uses a correlational research study which aims to determine how much the contribution between the studies variables are. Correlation study was a descriptive study used to determine the extent to which two or more variables are related so that the size of the relationship is determined through the use of the correlation coefficient.

Variables have an important role in a study, because it is impossible for a researcher to conduct research without the variables. Variable is defined as a concept that has variation or diversity (Setyosari,2015:163) stated that the variable in general is anything that becomes the object of observation in research. The variables in this study consisted of dependent variables, namely variables that were due to the existence of independent variables and independent variables, namely 
variables that influenced and had a relationship with other variables. The dependent variable in this study was the competence of science knowledge of class IV SDN Gugus III North Kuta for the $2019 / 2020$ academic year, while the independent variables in this study were naturalist ability and learning participation. This study paradigm has been described as follows.

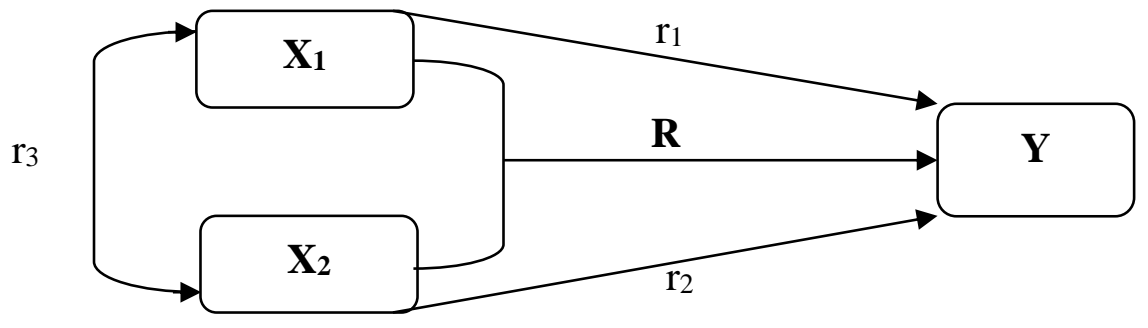

Figure 01. Research Paradigm

The paradigm of this study was made in such a way as to look for the relationship between naturalists' abilities to science knowledge competencies and learning participation on science knowledge competencies using simple correlation techniques, as well as looking for the relationship between naturalist abilities and learning participation against science knowledge competencies using multiple correlation techniques.

The population in this study were all fourth-grade students of SDN Gugus III North Kuta, consisting of 7 elementary schools, namely SD No. 1 Kerobokan, SD No. 2 Kerobokan, SD No. 3 Kerobokan, SD No. 4 Kerobokan, SD No. 1 Kerobokan Kaja, SD No. 2 Kerobokan Kaja, and SD No. 3 Kerobokan Kaja, totaling 490 people. The sampling technique in this study was proportional random sampling technique. Determination of sample size was using the Isaac and Michael table, according to the table at the level of education used an error rate of $5 \%$ and the minimum number of samples taken with an error rate of $5 \%$ was 205 people. Therefore, the total sample of each primary school was 214 people.

The data collection method used in this study was the non-test technique. The non-test techniques in this study were questionnaires / questionnaires and document recording. The questionnaire instrument was used to measure naturalist abilities and student learning participation, while document recording was used to obtain student science knowledge competency scores obtained through test scores in semester 1 of the 2019/2020 academic year. The questionnaire was prepared based on the indicators of each research variable. As for indicators of naturalist abilities, namely showing a deep interest in plants and animals, likes to grow crops and raise and care for animals, likes to do outdoor activities, has a good interest and understanding of topics / projects related to nature, shows sensitivity to patterns nature, knowing the types of rocks, fossils, flora, and fauna, having fun when you are in a garden, park, aquarium, or other open nature, having a belief that animals have their own rights, and are fond of collecting records about animals, plants and things of a kind. Meanwhile, there are indicators of learning participation, namely participation in questions, participation in answering, completing given assignments, participation in group discussions, recording teacher explanations, being able to solve questions on the blackboard, completing tests individually, and concluding the material at the end of the lesson. The type of questionnaire used in this study was a closed questionnaire designed to collect data about the circumstances experienced by the respondent himself. Then, all alternative answers that the respondent must answer have been included in the questionnaire. Alternative answers to the questionnaire using a Likert scale measurement. The answer to each instrument item used a Likert scale that has a gradient from very positive to very negative. The naturalist ability questionnaire consists of 32 statements, namely 18 positive statements and 14 negative statements, while the learning participation questionnaire consists of 34 statements, namely 20 positive statements and 14 negative statements.

Before the instrument was distributed, the validity and reliability tests were carried out. The validity test used was the construct validity test and the item validity test. The construct validity test was carried out based on the theories regarding the concept of the variable to be measured through a reasonable and careful analysis and comparison process, while the item validity test was used to show the quality of the item items of an instrument before they could be used as part of the test. Sugiyono (2018) declared valid meant that the instrument can be used to measure what should be measured. The question or item has high validity if the score on the item is equivalent to the total 
score. This equivalence is defined as correlation so that to determine the validity of the items, the product moment correlation formula is used. After testing the instrument, there were 32 valid statements for the naturalist ability questionnaire and 34 valid statements for the learning participation questionnaire. Instrument reliability test is related to the accuracy of the results. Sugiyono (2018) stated that a reliable instrument is an instrument that when used several times to measure the same object, will produce the same data. In other words, the reliability test is carried out to determine the level of stability of the measuring instrument. In this study, to measure the reliability of the naturalist ability questionnaire and learning participation using the help of Microsoft Excel 2010 with the Alpha Cronbach formula. The results of the reliability test of the naturalist ability questionnaire were 0.916 and the learning participation questionnaire was 0.953 . It can be stated that the reliability is very high.

Before the data analysis test, the analysis prerequisite test was carried out which consisted of the normality test, linearity test, multicollinearity test, and heteroscedasticity test. In testing the hypothesis, researchers used multiple linear regression analysis. Multiple linear regression analysis is used to estimate the size of the regression coefficient which shows the magnitude of the influence of the two predictor variables on the criterion variable. Multiple linear regression analysis is also used to find a functional relationship between two or more independent variables and the dependent variable. The hypothesis tested in this study is the null hypothesis (H0), namely, (1) there is no significant effect of naturalist ability on the fourth-grade students' competency in science knowledge of SDN Gugus III Kuta Utara for the 2019/2020 academic year (2) there is no significant effect. Participation in learning on the competence of science knowledge of class IV SDN Gugus III Kuta Utara for the 2019/2020 academic year, and (3) there is no significant effect on the naturalist ability and participation in learning on the competency of science knowledge of class IV SDN Cluster III North Kuta Academic Year 2019 / 2020.

\section{Result and Discussion}

The data obtained from this study were the students 'science knowledge competency scores, the results of the naturalist ability questionnaire and the fourth grade students' participation in SDN Gugus III Kuta Utara for the 2019/2020 academic year. The results of the analysis of the research data description obtained can be seen in table 01 .

Table 01. Results of Data Description Analysis

\begin{tabular}{cccc}
\hline Statistic & $\begin{array}{c}\text { Science Knowledge } \\
\text { Competencies }\end{array}$ & Naturalist Abilities & $\begin{array}{c}\text { Participation in } \\
\text { Learning }\end{array}$ \\
\hline Mean & 85,201 & 102,355 & 104,481 \\
Mode & 86,754 & 106,136 & 99,5 \\
Median & 79,685 & 88,646 & 87,70 \\
Standard Deviation & 7,446 & 14,497 & 16,48 \\
Variance & 55,448 & 210,174 & 271,603 \\
Minimum Score & 70 & 71 & 70 \\
Maximum Score & 100 & 128 & 136 \\
\hline
\end{tabular}

In this study, the analysis prerequisite test was carried out, namely the normality test, linearity test, multicollinearity test, and heteroscedasticity test. The normality test is used to see the score of the variable under study whether it follows a normal distribution or not. The normality test in this study used the Kolomogorov - Smirnov test. The test criteria for the normality test is that if $\mathrm{K}$ count $<$ Kstable, it can be stated that the data is normally distributed (Cahyono, 2015). The results of the normality test can be seen in table 02 .

Table 02. Data Normality Test Results

\begin{tabular}{cccc}
\hline Variable & Ks count & Kstable & Conclusion \\
\hline $\begin{array}{c}\text { Naturalist Ability to Science } \\
\text { Knowledge Competencies }\end{array}$ & 0,064 & 0,093 & Data is normally distributed \\
Participation in Learning Science & 0,037 & 0,093 & Data is normally distributed
\end{tabular}

Knowledge Competencies 
Naturalist Ability and Learning

Data is normally distributed

Participation in Science Knowledge

Competencies

Based on the results of the calculation of the normality test that Kcount <Kstable, it can be said that the data is normally distributed. A good regression model must have a residual value that is normally distributed. The results of the residual normality test can be seen in table 03 .

Table 03. Residual Data Normality Test Results

\begin{tabular}{cccc}
\hline Variable & Ks $\mathbf{s o u n t}_{\text {rable }}$ & Ks & Conclusion \\
\hline $\begin{array}{c}\text { Naturalist Ability to Science } \\
\text { Knowledge Competencies } \\
\text { Participation }\end{array}$ & 0,06 & 0,093 & $\begin{array}{c}\text { Data is normally } \\
\text { distributed } \\
\text { Data is normally } \\
\text { distributed }\end{array}$ \\
$\begin{array}{c}\text { Learning against Science } \\
\text { Knowledge Competencies }\end{array}$ & 0,051 & 0,093 & $\begin{array}{c}\text { Data is normally } \\
\text { distributed }\end{array}$ \\
\hline
\end{tabular}

Based on the results of the calculation of the residual normality test data K count <Kstable, it can be said that the data is normally distributed. The next analysis prerequisite test, namely the linearity test, was used to determine the form of the relationship between the dependent variable (Y) and the respective independent variables (X1 and X2). Linearity test includes the second analysis prerequisite test. Linearity test was used to determine whether the data were linear or not. The linearity test consisted of two stages, namely the regression direction significance test and the regression linearity test. Koyan (2012:106) stated the criteria used in the linearity test, namely if Fregression $>$ Ftable then Fregression means significant and if Funa fits $<$ Ftable then variables $\mathrm{X}$ and Y have a linear relationship. The results of the linearity test can be seen in table 04 and table 05 .

Table 04. Results of the Regression Direction Significance Test

\begin{tabular}{cccc}
\hline Variable & Frgression $_{\text { }}$ & $\mathbf{F}_{\text {table }}$ & Conclusion \\
\hline Naturalist Ability to Science Knowledge Competencies & 131,495 & 3,886 & Significant \\
Participation in Learning Science Knowledge Competencies & 184,994 & 3,886 & Significant \\
\hline
\end{tabular}

Table 05. Regression Linearity Test

\begin{tabular}{cccc}
\hline Variable & $\mathbf{F}_{\text {tuna cocok }}$ & $\mathbf{F}_{\text {table }}$ & Conclusion \\
\hline Naturalist Ability to Science Knowledge Competencies & 0,963 & 1,467 & Linear \\
Participation in Learning Science Knowledge & 1,142 & 1,459 & Linear \\
Competencies & & & \\
\hline
\end{tabular}

Based on the results of the linearity test that has been obtained, the meaningfulness test of the direction of regression and the linearity regression test of the naturalist ability and learning participation on the competence of science knowledge are significant and linear. Furthermore, the multicollinearity test was carried out to determine whether there was a high correlation between each independent variable in the regression model. To find out the multicollinearity in a variable, it can be seen from the VIF (Variance Inflation Factor) value or the Tol (Tolerance) value. The presence or absence of multicollinearity symptoms can be seen from the VIF and Tol values. If VIF $<10$ and Tolerance> 0.10, it can be stated that there is no multicollinearity (Purnomo, 2016). The multicollinearity test in this study used the SPSS 21.0 for windows program. The multicollinearity test results can be seen in table 06.

Table 06. Multicollinearity Test Results

\begin{tabular}{cccc}
\hline Variable & Tolerance & VIF & Conclusion \\
\hline Naturalist Abilities & 0,365 & 2,738 & Multicollinearity does not occur \\
Participation in Learning & 0,365 & 2,738 & Multicollinearity does not occur \\
\hline
\end{tabular}


Based on the results of the multicollinearity test, the naturalist ability data and learning participation data both obtained Tolerance values $(0.365)>0.1$ and VIF values $(2.738)<10.0$, it can be concluded that multicollinearity did not occur. The last prerequisite test is the heteroscedasticity test which is used to determine whether or not there is an inequality of variants of the residuals for all observations in the regression model. The heteroscedasticity test in this study was tested using the Glejser method. This heteroscedasticity test calculation uses the SPSS 21.0 for windows program. If the significant value between the independent variable and the absolute residual value $>0.05$, it can be stated that the data includes homoscedasticity (Purnomo, 2016). The results of the heteroscedasticity test can be seen in table 07.

Tabel 07. Heteroscedasticity Test Results

\begin{tabular}{ccc}
\hline Variable & Sig. & Conclusion \\
\hline Naturalist Abilities & 0,609 & Heteroscedasticity does not occur \\
Participation in Learning & 0,693 & Heteroscedasticity does not occur \\
\hline
\end{tabular}

Based on the results of the heteroscedasticity test, the naturalist ability obtained the Sig. (0.609)> 0.05 can be stated that there is no heteroscedasticity. The results of the SPSS test for learning participation data obtained the Sig. (0.693)> 0.05 can be stated that there is no heteroscedasticity. After testing the prerequisite analysis, it is continued with hypothesis testing.

Testing hypothesis, I was tested by simple linear regression analysis to obtain the result that the naturalist ability (X1) and science knowledge competence (Y) have a significant effect. This is evidenced by the results of the t test calculation, namely tcount (11.467) > ttable (1.971). Therefore, $\mathrm{HO}$ which states that there is no significant effect of naturalist ability (X1) on science knowledge competence $(\mathrm{Y})$ is rejected and Ha which states that there is a significant effect on naturalist ability (X1) on science knowledge competence (Y) is accepted. In simple linear regression analysis, the results of the regression equation are $=52.673+0.318 \mathrm{X}$. Based on the results of the regression equation that has been obtained, every 1-time increase in the naturalist ability unit causes an increase of 0.318 in the competency value of science knowledge at a constant of 52.673. Based on these reviews, the correlation coefficient of the naturalist ability variable with the science knowledge competency is 0.619 . With the effective contribution of the naturalist ability variable to the science knowledge competency of $12.68 \%$ while the residue is $87.32 \%$ influenced by other factors. The high and low naturalist abilities of students are influenced by several factors, namely internal factors and external factors (Pingge, 2016).

Hypothesis testing II was tested by simple linear regression analysis to obtain the result that learning participation (X2) and science knowledge competence (Y) had a significant effect. This is evidenced by the results of the $t$ test calculation, namely $t$ count (13.601) $>t$ table (1.971). Therefore, $\mathrm{H} 0$ which states that there is no significant effect of learning participation (X2) on science knowledge competence $(\mathrm{Y})$ is rejected and $\mathrm{Ha}$ which states that there is a significant effect on learning participation (X2) on science knowledge competence $(\mathrm{Y})$ is accepted. In simple linear regression analysis, the results of the regression equation are $=52.975+0.308 \mathrm{X}$. Based on the results of the regression equation that has been obtained, each increase of 1 time the learning participation unit causes an increase of 0.308 in the science competency value of science at a constant of 52.975. Based on these reviews, the correlation coefficient of the naturalist ability variable with the science knowledge competency is 0.683 . With the effective contribution of the naturalist ability variable to the science knowledge competency of $35.44 \%$ while the residue is $64.56 \%$ influenced by other factors.

Hypothesis testing III was tested by multiple linear regression analysis to obtain the result that the naturalist ability (X1) and learning participation (X2) on science knowledge competence (Y) had a significant effect. This is proven by the results of the calculation of the $\mathrm{F}$ test, namely Fcount (97.906) > Ftable (3.039), then HO (III) which states that there is no significant effect on naturalist ability (X1) and learning participation (X2) on the competence of science knowledge (Y) is rejected and $\mathrm{Ha}$ which states that there is a simultaneous influence on naturalist ability (X1) and learning participation (X2) on science knowledge competence (Y) is accepted. In multiple linear regression analysis, the results of the regression equation are $=49.909+0.105 \mathrm{X} 1+0.235 \mathrm{X} 2$. Based on the results of the regression equation that has been obtained, each increase of 1 time the naturalist ability unit and 1 time learning participation unit causes an increase in the naturalist ability of 0.105 and learning participation of 0.235 , the value of competency in science knowledge is at a constant of 49.909. Together, the correlation coefficient of the two variables of naturalist ability and learning 
participation with the competence of science knowledge in students is 0.694 and the coefficient of determination is 0.481 . Thus it can be interpreted that the contribution of the two variables to the competence of science knowledge is $48.12 \%$. The contribution of naturalist abilities and learning participation to the competence of science knowledge of class IV SDN Gugus III Kuta Utara for the $2019 / 2020$ academic year amounted to $48.12 \%$. These results indicate that $51.88 \%$ of science knowledge competence is influenced by other factors. These factors include internal factors which include interests and talents, motivation, readiness of students and external factors which include the learning environment, learning methods and models, and family parenting. Therefore, it can be stated that naturalist ability and learning participation are able to influence students' competency in science knowledge (Jefri, 2019).

Based on the research results that have been described previously, information was obtained, namely the ability of naturalists to have a significant positive effect on the competence of science knowledge by $12.68 \%$. The results of this study are related and produce the same findings as previous research that has been carried out by Lesmana (2016) that is, there is a significant positive effect between the naturalists' ability on the learning outcomes of science learning materials of plants and animals in grade IV by $20 \%$. This can happen because the naturalist's ability is related to the science study regarding materials about nature, flora / fauna, and the surrounding environment which makes students quickly have an interest in science learning activities designed by the teacher without any burden on the student. This is in accordance with the opinion Anna (2016) that elementary school-age children are true naturalist creatures, with high naturalist abilities they easily feel happy and enthusiastic when learning about animals and plants or doing activities related to nature. Through activities in science learning about nature and the surrounding environment designed by the teacher, it will be able to hone and improve the naturalist abilities of each student and will have an impact on the competencies possessed, especially the competence of science knowledge. Therefore, the higher the naturalist ability of the student, the higher the competence of science knowledge that the student has, and vice versa, the lower the naturalist intelligence of the student, the lower the student's science competency achievement results.

In addition to naturalist abilities, the results of research conducted by researchers also showed that learning participation had a significant positive effect on the competence of science knowledge by $35.44 \%$. The results of this study are related and produce the same findings as previous research that has been carried out by Arini (2018) that is, participation in learning has a positive effect on science learning outcomes by $40.1 \%$. In addition, research by Syaikhuddin dan Sami'an, (2017) juga menunjukkan bahwa partisipasi siswa dalam pembelajaran berpengaruh positif terhadap student learning outcomes of $36.1 \%$. The results of these studies can be said to be interrelated because learning participation both play an important role in increasing the achievement of student learning outcomes. This is in line with opinion Wijayanti (2013) that the process of learning activities carried out by the teacher is said to be successful, including if there is an increase in student participation which can affect the increase in student learning outcomes. Therefore, it can be said that learning participation has a relationship with the achievement of competence in science knowledge and cannot be separated. With the participation of students learning, learning will be more focused on educating and developing the potential and competency aspects of student science knowledge towards a more optimal direction. Therefore, the higher the student's learning participation, the more the student's competence in science knowledge, and vice versa, the lower the student's participation, the student's competence in science knowledge will not be achieved optimally.

From the presentation of the results of this study, it has been proven that naturalist abilities and student participation have a significant effect on the achievement of competency in science knowledge. In this study, naturalist abilities and learning participation had an effect of $48.12 \%$. This shows that the competence of science knowledge competency is influenced by the ability of naturalists and learning participation simultaneously because the content of science learning in elementary schools teaches students about living things and their life processes, the earth and the universe which have a relationship with naturalist abilities that are able to foster student curiosity so that students will feel enthusiastic when learning about all activities / activities related to nature and will be encouraged to participate very easily during the learning process. Students will be able to think critically, creatively and innovatively and have a good interpretation of science materials taught by the teacher because naturalist abilities and student participation spur students to be able to think more optimally. Therefore, it is evident that the higher the naturalist ability and student participation, the more optimal the achievement of the student's competence in science knowledge. 


\section{Conclusion}

Referring to the results of the study and discussion that have been reviewed, the conclusion is that there is a significant influence between the naturalist ability of the fourth grade students of SDN Gugus III Kuta Utara with a contribution of $12,68 \%$, there is a significant influence between learning participation and competence. IPA knowledge of class IV SDN Gugus III Kuta Utara with a contribution of $35,44 \%$ and there is a significant influence between naturalist ability and learning participation on the science knowledge competence of grade IV SDN Gugus III Kuta Utara together with a contribution of $48,12 \%$.

\section{References}

Agung, A. A. G. (2014). Buku Ajar Metodologi Pendidikan. Malang: Aditya Media Publishing.

Anna, C. (2016). Hubungan Kecerdasan Naturalis Dengan Sikap Peduli Lingkungan Siswa Kelas Iii Sd Se-Kecamatan Gondokusuman. Jurnal Pendidikan Guru Sekolah Dasar, 5(25), 411-425. http://journal.student.uny.ac.id/ojs/index.php/pgsd/article/view/4226

Arikunto, S. (2010). Prosedur Penelitian Suatu Pendekatan Praktik. Jakarta: PT. Rineka Cipta.

Arini, D. (2018). Hubungan Kecerdasan Logis Matematis dan Partisipasi Belajar dengan Nilai Hasil Belajar Siswa pada Mata Pelajaran IPA di SD IT Insantama. Jurnal Pendidikan, 1, 1. http://pkm.uika-bogor.ac.id/index.php/PTP/article/view/102

Cahyono, T. (2015). Statistik Uji Normalitas. Purwokerto (Purwokerto: (ed.)). Yayasan Sanitarian Banyumas.

Holili, H. (2018). Membangun Aktualiasi Pembelajaran Dengan Teori Kecerdasan Majemuk. AlInsyiroh: Jurnal Studi Keislaman, 2(2), 65-83. https://doi.org/10.35309/alinsyiroh.v2i2.3322

Husin, A. (2017). Pengaruh Metode Pembelajaran dan Kecerdasan Naturalis Terhadap Pengetahuan Siswa Tentang Konsep Ekosistem (Eksperimen di Sekolah Dasar Negeri 4 Tangerang). Jurnal Ilmiah Pendidikan Lingkungan Dan Pembangunan, 13(2), 53. https://doi.org/10.21009/PLPB.132.05

Istiana, R. (2017). Analisis Partisipasi Siswa Dalam Menjaga Kesehatan Lingkungan Ditinjau Melalui Kecerdasan Naturalis. Jurnal Pendidikan Biologi, 1, 1. https://doi.org/10.24114/ipb.v7i1.9234

Jefri, J. (2019). Penerapan Model Talking Stick Untuk Meningkatkan Partisipasi Belajar Siswa Pada Pembelajaran Sosiologi Kelas X IPS 1 SMA Negeri 3 Bukittinggi 2019. Jurnal Perspektif, 2, 3. http://dx.doi.org/10.24036/perspektif.v2i3.74

Juniarti, Y. (2015). Peningkatan Kecerdasan Naturalis Melalui Metode Kunjungan Lapangan (Field Trip). Pendidikan Usia Dini, 9(2). http://pps.unj.ac.id/journal/jpud/article/view/104

Koyan, I. . (2012). Statistik Pendidian: Teknik Analisis Data Kuantitatif. Singaraja: Universitas Pendidikan Ganesha Press.

Lesmana, F. (2016). Pengaruh Kecerdasan Naturalis Terhadap Hasil Belajar IPA Materi Tumbuhan dan Hewan di Kelas II Mi Al-Khoiriyyah 2 Semarang Tahun Pelajaran 2015/2016. Jurnal Pendidikan Universitas Islam Negeri Walisongo. http://eprints.walisongo.ac.id/id/eprint/6781

Lestari, K. P., Kt, D. B., Semara, N., Agung, I. G., \& Negara, O. (2018). Pengaruh Model Tipe Numbered Head Together Berbantuan Media Audio Visual terhadap Penguasaan Kompetensi Pengetahuan IPA Siswa Kelas IV SD Gugus Yos Sudarso . 2(1), 40-45. https://webcache.googleusercontent.com/search?q=cache:RRoYWpb tw]:https://ejournal.u ndiksha.ac.id/index.php/IISD/article/download/13895/8779+\&cd=1\&hl=en\&ct=clnk\&gl=id

Maryanti, S., Kurniah, N., \& Yulidesni, Y. (2019). Meningkatkan Kecerdasan Naturalis Anak Melalui Metode Pembelajaran Outing Class Pada Kelompok B Tk Asyiyah X Kota Bengkulu. Jurnal Ilmiah POTENSIA, 4(1), 22-31. https://doi.org/10.33369/jip.4.1.22-31

Nurhayati. (2016). Peningkatan Partisipasi dan Prestasi Belajar PKn dengan Model Pakem Siswa Sekolah Dasar. Pendidikan Sekolah Dasar, 2(1). http://dx.doi.org/10.12928/ipsd.v2i2.4949

Nurhayati, N. (2017). Peningkatan Partisipasi dan Hasil Belajar Siswa Kelas IVA dalam Pembelajaran Pai dengan Strategi True Or False di SD Negeri 21 Batang Anai. JPPI Uurnal Penelitian 
Pendidikan Indonesia), 3(2), 30. https://doi.org/10.29210/02017115

Pingge. (2016). Faktor yang Mempengaruhi Hasil Belajar Siswa Sekolah Dasar di Kecamatan Kota Tambolaka. Jurnal Prima Edukasia, 4, 2. https://doi.org/10.21831/ipe.v4i2.6458

Pramana. (2019). Kontribusi Kecerdasan Naturalis dan Sikap Peduli Sosial Terhadap Kompetensi Pengetahuan IPS Siswa Kelas IV SD. Jurnal Media Komunikasi FPIPS, 18, 2. http://dx.doi.org/10.23887/mkfis.v18i2.22244

Purnomo, R. A. (2016). Analisis Statistik Ekonomi dan Bisnis dengan SPSS. Ponorogo: Wade Group.

Rahman, I. F., Suryana, Y., \& Nugraha, A. (2018). Meningkatkan Kecerdasan Natralis melalui Metode Observation, Investigation dan Experiment dalam Materi Tumbuhan dan Hewan. PEDADIDAKTIKA: Jurnal Ilmiah Pendidikan Guru Sekolah Dasar. 5(3), 120-128. https://ejournal.upi.edu/index.php/pedadidaktika/article/view/12914

Santiani, N. W., Sudana, D. N., \& Tastra, I. D. K. (2017). Pengaruh Model PBL Berbantuan Media Konkret terhadap Hasil Belajar IPA Siswa Kelas V SD. E-Journal PGSD Universitas Pendidikan Ganesha, 5(2), 1-11. http://dx.doi.org/10.23887/ijpgsd.v5i2.10826

Santoso, M. (2018). Penerapan Metode Ceria Permanis Untuk Meningkatkan Partisipasi dan Prestasi Belajar PKn Siswa Kelas VII SMPI Hidayatul 'Ulum Dayu Semester Genap Tahun Pelajaran 2017/ 2018. Jurnal Pendidikan \& Pembelajaran, $10,2$. https://doi.org/10.35457/konstruk.v10i2.511

Setyosari, H. P. (2015). Metode Penelitian Pendidikan dan Pengembangan. Jakarta: Kencana Prenadamedia Group.

Shodiq, J., Saputra, R. R., Kuswara, H., \& Presenetation, I. M. (2020). Penerapan Strategi Pembelajaran Intelligence Mapping Presentation untuk Meningkatkan Partisipasi. 8(1), 65-72. http://journal.ipts.ac.id/index.php/ED/article/view/1500

Siti Nurjanah. (2018). Perkembangan Nilai Agama dan Moral (STTPA TERCAPAI). Paramurobi, 1(1). https://webcache.googleusercontent.com/search?q=cache:vYDstRumWGoJ:https://ojs.unsiq. ac.id/index.php/paramurobi/article/download/177/74+\&cd=2\&hl=en\&ct=clnk\&gl=id

Sugiyono. (2018). Metode Penelitian Pendidikan. Bandung: Alfabeta.

Sunhaji. (2014). Konsep Manajemen Kelas dan Implikasinya dalam Pembelajaran. Kependidikan, 2(2). https://doi.org/10.24090/jk.v2i2.551

Susilowati. (2014). Pembelajaran IPA pada Kurikulum 2013. Makalah Universitas Negeri Yogya. http://staffnew.uny.ac.id/upload/198306232009122005/pengabdian/penguatan-contentknowledge-keintegrasian-materi-ipa-dalam-implementasi-kurikulum-2013.pdf

Syaikhuddin dan Sami'an. (2017). Pengaruh Partisipasi Siswa Dalam Pembelajaran Dan Proporsi Waktu Belajar Terhadap Hasil Belajar Ips Pada Siswa Kelas VIII SMP Muhammadiyah 05 Kayen Pati Tahun Pelajaran 2016/2017. http://eprints.ums.ac.id/id/eprint/46895

Syarifah, S. (2019). Konsep Kecerdasan Majemuk Howard Gardner. SUSTAINABLE: Jurnal Kajian Mutu Pendidikan, 2(2), 176-197. https://doi.org/10.32923/kjmp.v2i2.987

Widi, dkk. (2014). Metodologi Pembelajaran IPA. Jakarta: Bumi Aksara.

Wijayanti, N., \& Kusrini. (n.d.). Hubungan kecerdasan emosional terhadap partisipasi belajar dan pemahaman matematika siswa sman 2 magetan kelas $x 3$. https://jurnalmahasiswa.unesa.ac.id/index.php/mathedunesa/article/view/4033

Yaumi, M. (2013). Pembelajaran Berbasis Kecerdasan Jamak (Multiple Intelligences) Mengidentifikasi dan Mengembangkan Multitalenta Anak. Jakarta: Kencana. 